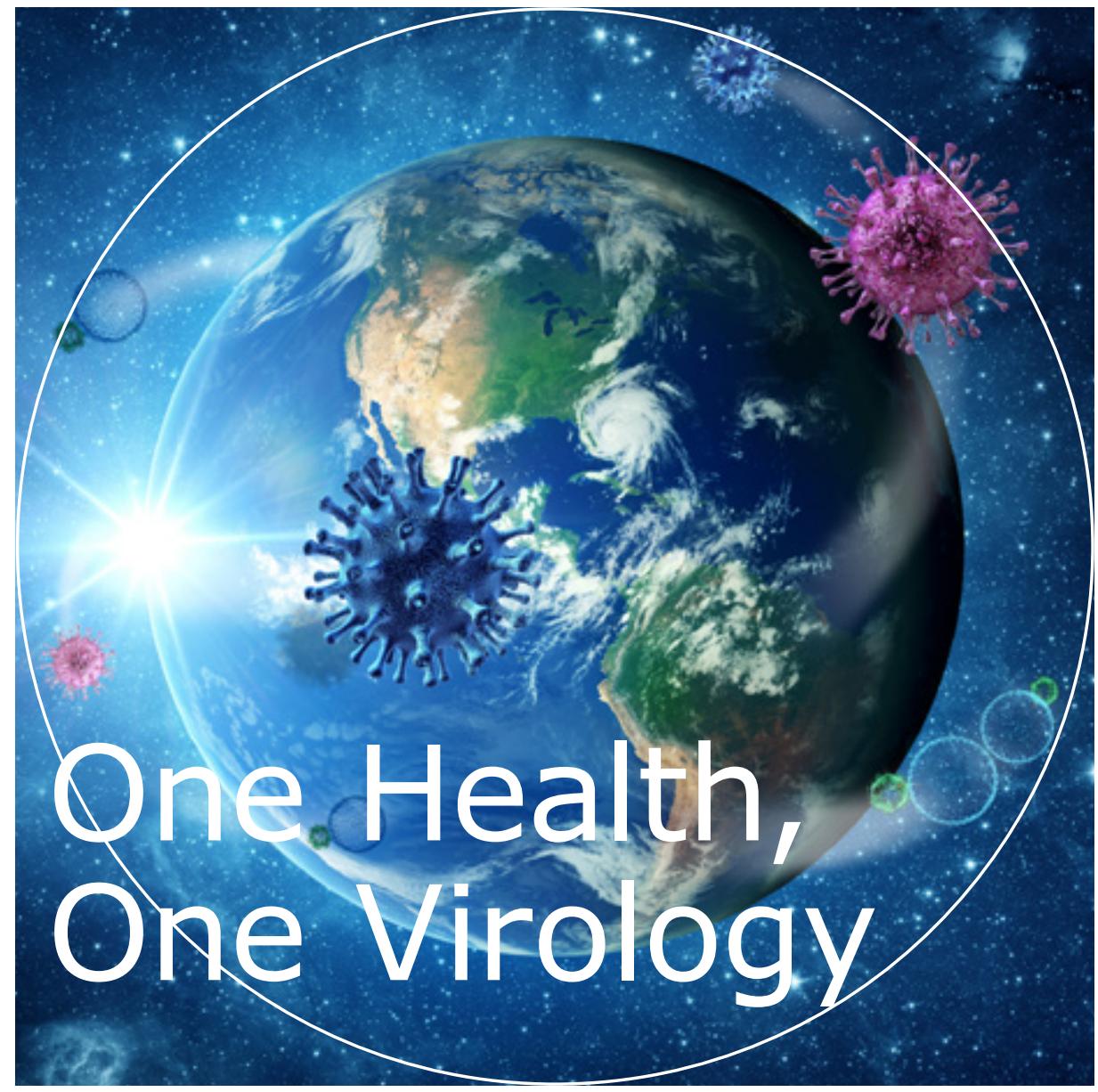

Prof.dr Wim H. M. van der Poel

Inaugural lecture upon taking up the position of Special Professor of Emerging and Zoonotic Viruses at Wageningen University \& Research on 6 June 2019 



\section{One Health, One Virology}

\section{Prof.dr Wim H. M. van der Poel}

Inaugural lecture upon taking up the position of Special Professor of

Emerging and Zoonotic Viruses at Wageningen University \& Research on 6 June 2019 
DOI https://doi.org/10.18174/478362

ISBN 978-94-6343-789-9

(C) All rights reserved 


\section{One Health, One Virology}

Esteemed Rector Magnificus, dear family, friends, colleagues, ladies and gentlemen, I am honoured to stand here in front of you in the Aula of Wageningen University to present my inaugural lecture upon taking up the position of Special Professor of 'Emerging and Zoonotic Viruses'. In this lecture I will talk about current approaches in this field of research and explain about my plans for research and education.

\section{A virus outbreak wakeup call}

Let me take you back to the year 2003. On 12 March, the World Health Organisation (WHO) issued a worldwide alert about cases of atypical pneumonia caused, most likely, by a new infectious agent. Since midFebruary, cases of severe pneumonia had been reported in Hong Kong, Vietnam and the Guangdong province in China. Symptoms included an initial flu-like illness with rapid onset, followed by muscle pain and headache. Patients manifested a bilateral pneumonia, in some cases progressing to acute respiratory distress. The outbreak seemed to have started in Guangdong. China reported 305 cases of atypical pneumonia in this region in mid-February and five people died. Investigations into the cause of the outbreak had not yielded any clues yet. WHO recommended isolating patients with atypical pneumonia possibly related to these outbreaks and caring for them with barrier nursing techniques. WHO also recommended reporting any suspect cases to national health authorities. The situation worsened: Within a few days people returning to Toronto from Hong Kong showed symptoms of the disease. So just three days after the first global alert, WHO issued a heightened global health alert about the mysterious pneumonia, and added a case definition of the disease. In March and April, WHO and the Centers for Disease Control (CDC) in Atlanta, issued travel warnings. All non-essential travel to Hong Kong and Guangdong province in China should be postponed. 
The highly alarming situation I have just described is the SARS outbreak. Today SARS is still remembered as one of the most frightening disease outbreaks ever in humans. During the outbreak, and in subsequent years, much research was done to find the cause of the disease, to characterize the agent, and to clarify why it spread so quickly.

The most likely index case of SARS was a 46-year-old man in Foshan. He had helped in a kitchen cooking wild meat. Shortly after, he developed a severe atypical pneumonia with headache and fever. The same symptoms were seen in dozens of people in the Guangzhou region. One of the patients was a fish trader who ran a stall on the market. He was treated in Guangzhou hospital where he infected more than 20 healthcare workers, including a young doctor. The doctor travelled to Hong Kong for his brother's wedding. He stayed in the Metropole hotel where he fell ill and infected sixteen other guests and a visitor to the hotel. Some of these people travelled over the next few days to Canada and Singapore. This was the start of the intercontinental spread of the infectious disease.

Identifying the cause of this new disease was difficult back in 2003. First, a series of pathogens, including influenza and mycoplasma, seemed to be associated with disease cases. Eventually, Dr Malik Peiris and his team at the Pasteur Research Centre, University of Hong Kong cultured a virus on vero cells taken from respiratory tract samples and identified a coronavirus by electron microscopy. Peiris and his team neutralized the culture using antibody-positive serum from infected patients. That proved this virus was the cause of the disease. As soon as the virus was identified, specific diagnostic methods could be developed and targeted control strategies implemented. First of all, however, biosecurity measures were used to reduce the number of new cases. Isolation of symptomatic patients played a major role in the control of SARS. This was so effective because people infected with SARS showed symptoms near the start of their infectious period. Health authorities could therefore isolate most infected persons before they infected somebody else. On 5 July 2003, almost five months after the SARS outbreak started, WHO declared the world SARS-free.

The SARS outbreak had a huge negative impact on the economy and society. It created international anxiety due to its novelty, ease of transmission in certain settings, fast spread through jet travel and the extensive media coverage it received. Western media were blamed for focussing too much on the negative aspects. Their coverage made people more frightened of SARS 
than they needed to be. Conferences in China were cancelled, and people postponed their travel. Direct economic losses due to SARS were estimated to be more than 40 billion dollars.

\section{Animal viruses often infect humans too}

Almost $70 \%$ of all new infectious viruses in humans originate from animals. Viruses transmitted directly from vertebrate animals to humans are called zoonoses. SARS became a suspected zoonosis soon after the start of the outbreak. Many wild animals are traded on local markets in China. The authorities therefore tested these for SARS Coronavirus. The virus was soon isolated from masked palm civets (Paguma sp.) a forest animal hunted in China for its meat. SARS Coronavirus was believed to have crossed the species barrier from Asian palm civet to humans. Many of these animals were subsequently killed. Later on, SARS-like coronaviruses were detected in Chinese horseshoe bats and extensive research on genetic evolution, receptor binding and pathogenesis demonstrated that SARS-CoV most likely originated in bats through sequential recombinations. Masked palm civets appeared to be intermediate hosts of the virus.

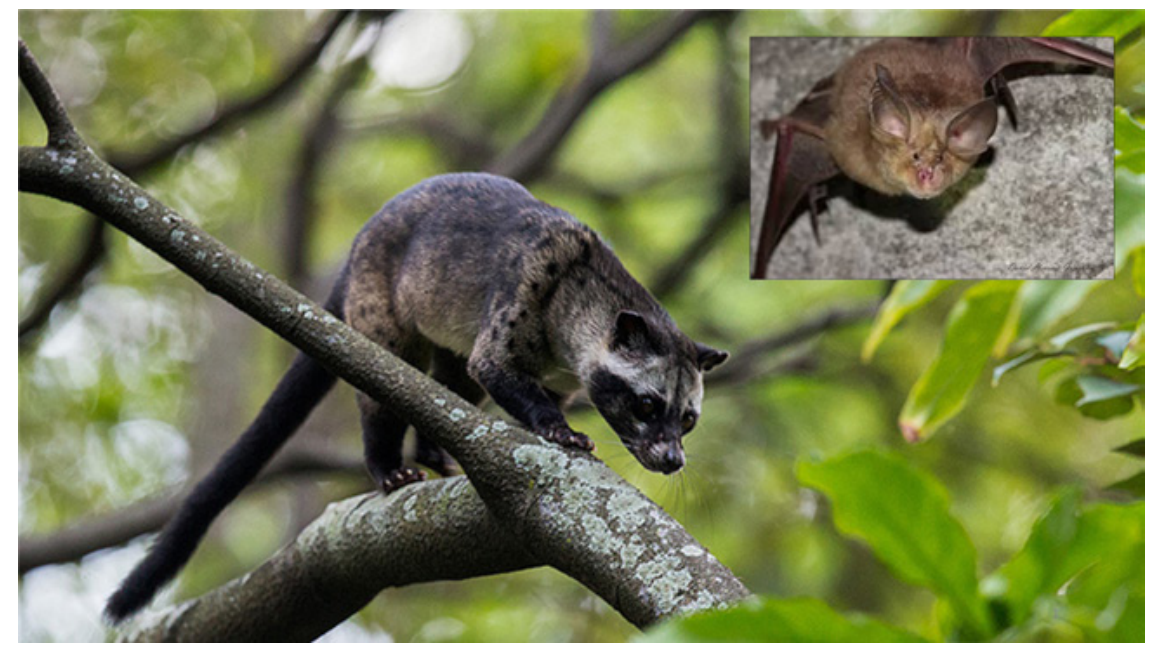

Asian Palm Civet cat (Paradoxurus hermaphroditus) and Chinese Horseshoe bat (Rhinolophus ferrumequinum). (C) Francis Yap Photography - WordPress.com 


\section{New approach needed}

The outbreak of SARS was a wake-up call for at least three main reasons:

First of all, it showed that a new disease outbreak can spread very rapidly over the world due to increasing travel and people having frequent contacts. Increasing transports may have a similar effect in the case of foodborne infections and animal infectious diseases. Secondly, media attention, which now includes social media, may cause considerable worldwide anxiety as soon as the first cases of an outbreak are reported. Thirdly, new emerging disease outbreaks are complex and challenging events. Every pathogen has its own specific traits and interaction characteristics with the host.

Transmission and spread strongly depend on people's behaviour. Therefore right from the start, public health workers and researchers from different disciplines must work closely together to quickly control a new disease outbreak and effectively prevent new outbreaks of infection. This need for collaboration has led to the current One Health approach that I will now explain.

\section{One Health}

The idea that human, animal and environmental health are linked can be traced back to ancient times. In his text "On Airs, Waters, and Places", the Greek physician Hippocrates $(460$ - 370 BC) promoted the concept that public health depended on a clean environment.

In the 19th century, scientists developed a strong interest in linking human and veterinary medicine. Rudolf Virchow is probably the best-known example. With the start of cellular pathology, these scientists developed a form of comparative medicine based on the discovery of similar disease processes in humans and animals.

Calvin Schwabe (1927-2006) seems to have coined the term "One Medicine". Schwabe was an American veterinarian who wrote extensively about the relationship between animal and human diseases (Wilhelmsson et al. 2013). The interrelationship between human and animal health is a pillar of the "One Medicine" concept, and recent disease outbreaks like Bovine Spongiform Encephalopathy (BSE) have underlined its importance. Comparative pathology showed that the sheep disease scrapie and the human variant Creutzfeldt-Jacobs Disease (CJD) were similar. Initially, the risk for humans was unclear. Later, however, the BSE epidemic in cattle gave rise to several hundred variant CJD cases. Exposure to BSE is now thought to have been the cause. This outbreak led to European governments and the EU 


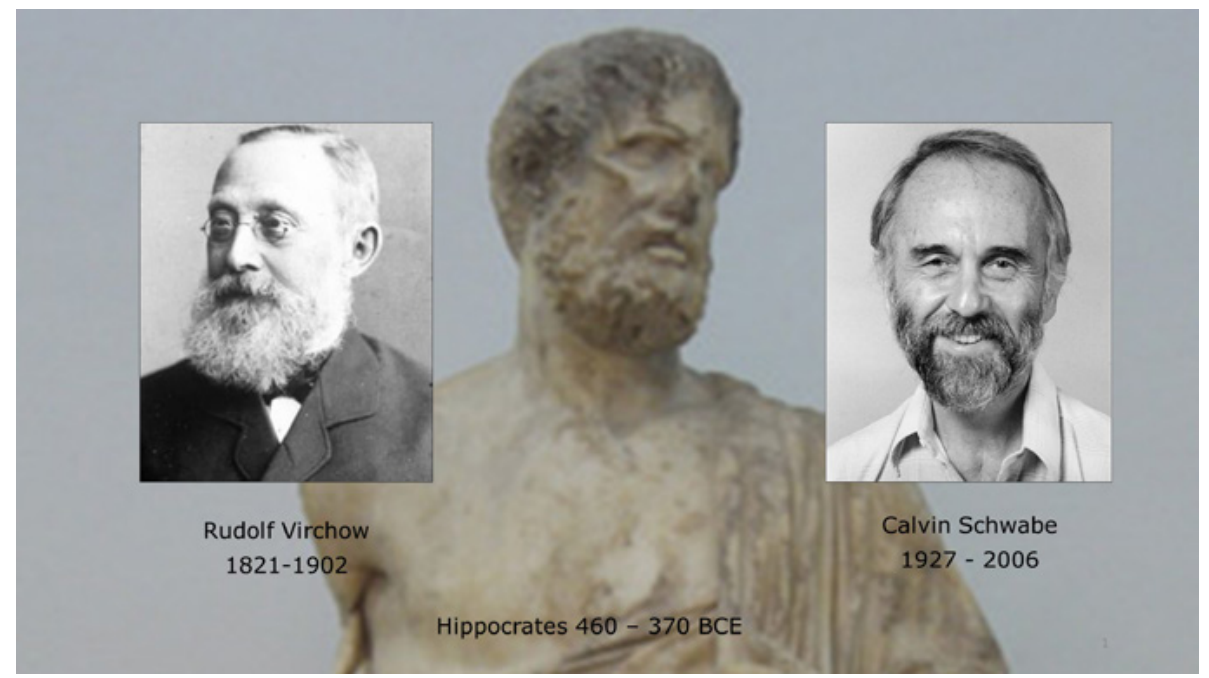

Hippocrates (460 - 370 before Christ), Rudolf Virchow (1821 - 1902) and Calvin Schwabe (1927 - 2006). Environmental Health, Comparative Medicine and One Medicine.

reconsidering who is the responsible authority for initiating and conducting risk assessment and management of diseases that affect both humans and animals. Ultimately, the BSE crisis created the conditions for establishing a joint European Food Safety Authority in 2002 (Budka 2011). It also highlighted the complexities of the food chain required for meat production and underlined the importance of considering health in a broader context.

This broader so-called "One Health" approach was further embraced in about round 2004, when fears arose that the highly pathogenic H5N1 avian influenza could cause a pandemic. One Health recognizes that humans do not exist in isolation. Rather they are part of a larger whole, a living ecosystem in which each member's activities affect the others. Whereas "One Medicine" historically implied links between veterinary and human medicine, One Health considers health as a whole: humans, animals, plants and environment they interact with. Nowadays the expression "One Health" has been adopted by many professionals: epidemiologists, physicians, veterinarians, wildlife specialists, and environmentalists. It is also used by many international organizations working on the control of zoonoses like the World Health Organisation (WHO), the Food and Agriculture Organisation (FAO) and the World Organisation for Animal Health (OIE). 
One Health can be defined as 'The collaborative effort of multiple health science professions, together with their related disciplines and institutions working locally, nationally, and globally - to attain optimal health for people, domestic animals, wildlife, plants, and our environment'. Inevitably, it is important to study infectious agents that may cross species and environmental barriers to move between these compartments.

\section{One Health needed for Hepatitis E}

Hepatitis $E$ is a disease that can only be controlled effectively using a One Health approach. Hepatitis $\mathrm{E}$ is an inflammation of the liver caused by infection with the hepatitis E virus. Disease symptoms include jaundice, fatigue and nausea. This virus has at least five different genotypes. Genotype 3 is the predominant genotype in Europe and has a very high prevalence in domestic swine worldwide. Each year, about 133,000 new infections with hepatitis E virus occur in the Netherlands. The main cause of infection is the consumption of raw or undercooked pork. However, the virus can also be transmitted via blood donations. In healthy people, infections usually run a subclinical course, but people with underlying liver disease or a hampered immune system may develop severe disease symptoms. Especially patients who receive blood products can develop an acute and chronic liver disease that may be fatal. Solid

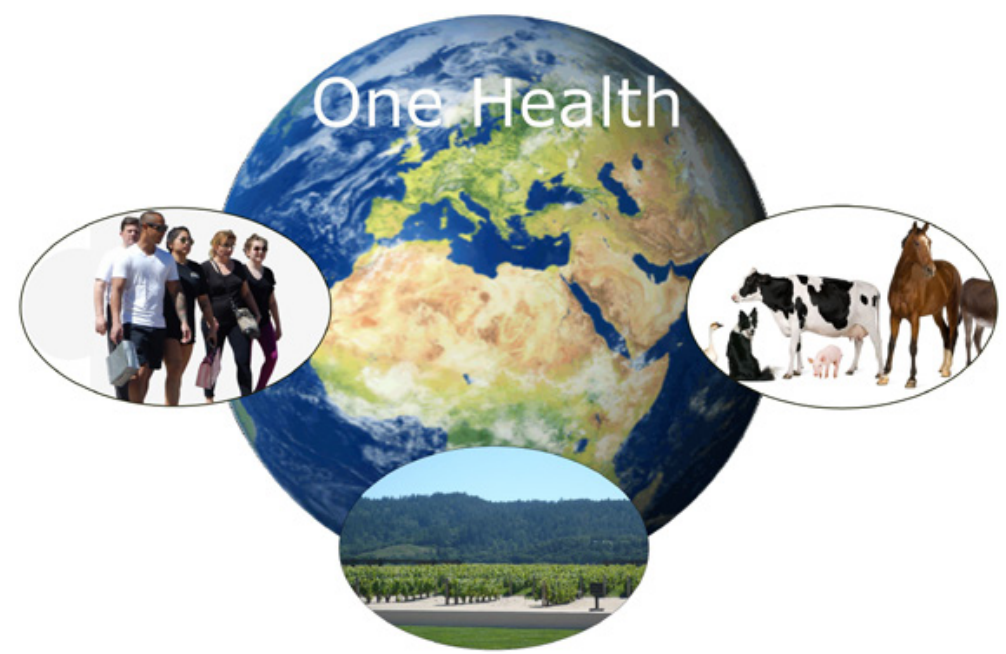

One Health, 'The collaborative effort of multiple health science professions, together with their related disciplines and institutions - working locally, nationally, and globally - to attain optimal health for people, domestic animals, wildlife, plants, and our environment'. 
organ transplant recipients who receive immunosuppressive drugs represent the majority of patients with chronic hepatitis E infection. In such cases, reduced administration of immunosuppressive drugs is often part of the clinical therapy and may lead to clearance of the hepatitis E infection. Antiviral therapy in the form of ribavirin monotherapy is the current treatment of choice for patients with chronic hepatitis E infection. About $85 \%$ of these patients show a sustained virological response.

The best way to control hepatitis E would be to eradicate the virus in the swine reservoir. However, that would be extremely difficult. The virus is highly contagious in pigs and can survive for a relatively long period in soil and water environments. Biosecurity and hygiene standards at farms would therefore have to be raised significantly. Moreover, as pigs suffer no symptoms, a vaccine to control the virus is not available. Pig farmers therefore have little incentive to combat hepatitis E infections. Recent studies show a rise in hepatitis E cases throughout Europe and in high-income countries outside Europe. The European Food Safety Authority (EFSA) acknowledged this several years ago and appointed a working group on hepatitis E virus in 2016. This working group, which I was a member of, published a scientific opinion on the public health risks of hepatitis E virus. They concluded that qualitative methods for detecting the virus should be developed together with more effective control measures. In the Netherlands, the Ministry of Health, Welfare and Sport commissioned the Health Council of the Netherlands to investigate the risk of hepatitis E virus contamination in blood products. The expert committee, which I was part of, concluded that testing for the virus in blood donations should be continued and that control measures in the food chain merited further research.

At Wageningen Bioveterinary Research, we have worked on hepatitis E virus for more than 15 years. In 2009, Martijn Bouwknegt completed his PhD on hepatitis $\mathrm{E}$ virus infections in pigs, transmission dynamics and human exposure. His research demonstrated that domestic pigs are a true reservoir of hepatitis E virus, which may be transmitted to humans directly or indirectly from the pork production chain. The next PhD on the virus in our group was Alessandra Berto, who worked on culturing the hepatitis E virus and the feasibility of a vaccination strategy on pig farms. This research was part of the EU project VITAL on "Control of foodborne viruses in food supply chains". A major breakthrough was the first ever culture of infectious hepatitis E virus from a ready-to-eat sausage. These research projects have contributed significantly to our understanding of hepatitis E virus 


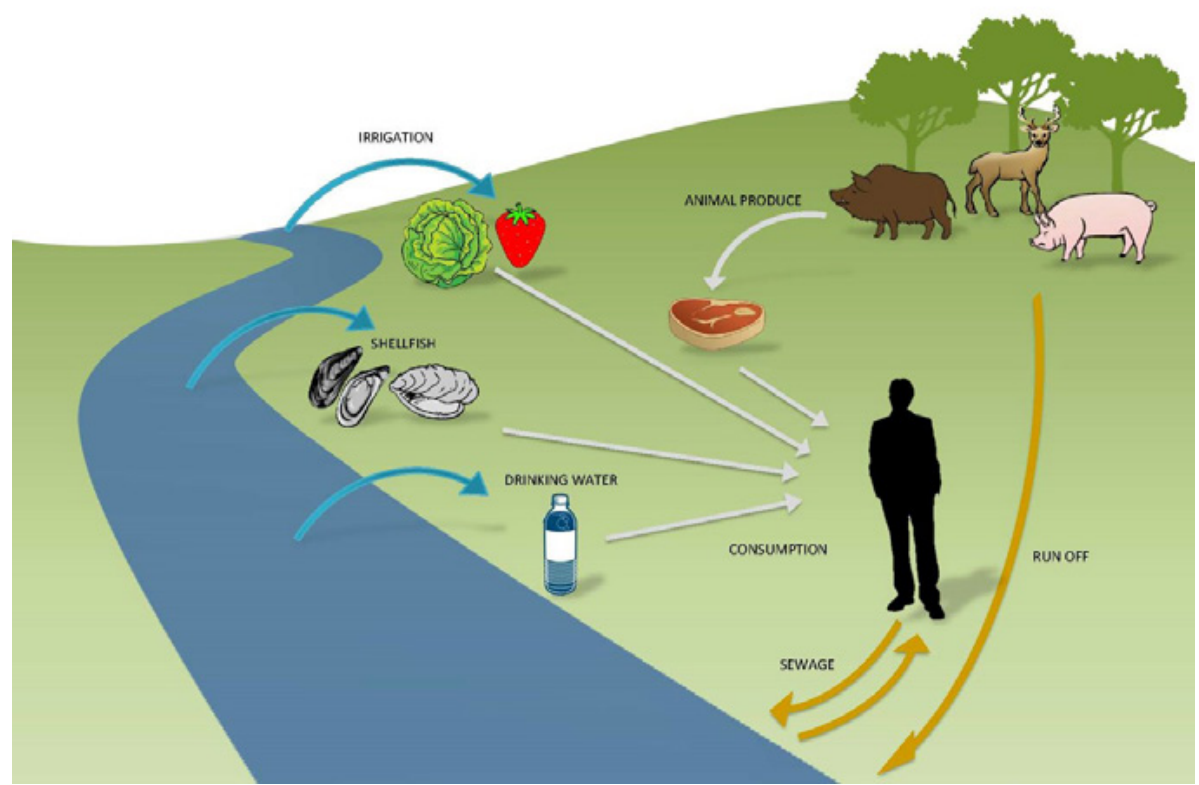

Food and Environmental Routes of Hepatitis E Virus Transmission.

contaminations and the associated public health threats. However, several important research objectives remain, and so our work in this field continues.

\section{Preparing for the unknown}

In 2015, the World Health Organisation produced a list of pathogens for research and development in public health emergency contexts. This list aims to clearly identify diseases that pose a public health risk because of their epidemic potential and for which countermeasures do not exist or are insufficient. This Blueprint list of priority diseases includes viruses like SARS-CoV and Ebola. In 2018, at the time of the second annual review, "Disease $X$ " was added to this list. Disease $X$ is the code name for an unknown pathogen, which may cause disease and potentially an epidemic in the future. It was added to the list of priority diseases as a "known unknown". This addition acknowledged the fact that a new epidemic might be caused by an unknown pathogen. Therefore diagnostic and medical preparedness that is also relevant for an unknown pathogen should be sought as much as possible. 
This WHO initiative clearly demonstrates the view of public health officials that more research is needed to better prepare us for unknown infectious diseases. Fortunately, as new pathogens with fresh diagnostic challenges have emerged in recent decades a molecular revolution in laboratory methods has also taken place. Several of these techniques target specific parts of virus genomes to detect and identify viruses. Development and implementation of these new molecular technologies have led to a tremendous increase in the success rates for virus discovery. I will now describe some of these extremely valuable molecular methods.

\section{Molecular detection and characterization methods \\ Polymerase chain reaction}

Polymerase chain reaction (PCR) was the first diagnostic technique based on nucleic acids to be described. Now it is the most widely used targeted nucleic-acid-based method in virology. In the technique, nucleic acids from clinical samples are exposed to cycles of heating and cooling. This repeatedly melts the DNA, and every time this is followed by enzymedriven DNA replication. The result is high concentrations of specific DNA fragments. These can be used in DNA fingerprint analyses or sequencing that identifies viruses based on their genomic composition. Nucleic acid amplification and the subsequent sequencing of overlapping fragments are used to determine complete genome sequences of viruses. Full genome sequencing can be done fragment by fragment, but that is a very laborious process. So now it is done with various deep-sequencing platforms. DNA is broken up randomly into numerous small segments, which are then sequenced. Multiple overlapping reads for the target DNA are obtained by performing several rounds of this fragmentation and sequencing process. Dedicated computer programs are used to assemble the overlapping ends of different reads and to collate all sequence information into a continuous viral genome sequence.

\section{Microarray}

In DNA microarray, a collection of specific DNA molecule stretches is printed on a solid surface, on which DNA isolates from test samples are incubated. The underlying principle is that hybridization occurs between two DNA strands due to hydrogen bonds forming between complementary nucleotide base pairs. Once unbound DNA fragments have been removed by washing, only strongly paired strands will remain hybridized. This hybridization is made visible by fluorescent labelling sequences that bind 
to a probe sequence. A signal is subsequently generated that depends on the hybridization conditions, such as temperature and washing after hybridization. The fluorescent signal can be read using a laser microscope and analyzed using a dedicated computer program. This DNA-on-a-chip method can be used to test several hundred viral DNA sequences simultaneously. The method is fast but not particularly cheap, and it relies on known sequences printed on the chip.

\section{Metagenomics}

Early viral genome sequencing relied on cultured viruses and cloned DNA. Now "shotgun" or PCR-directed, high-throughput sequencing are used to obtain largely unbiased samples of all genes from all viruses in a sample. This metagenomics approach, in which genetic material is recovered directly from samples, can reveal previously unobserved diversity and provide important information on virus evolution. In infectious disease research, metagenomics techniques are attractive because they allow all viruses in a clinical sample to be captured using a single protocol. However, this approach still requires standardization and validation. Furthermore, appropriate bioinformatics analysis is needed in all cases to cope with the vast amounts of data generated. Laboratories have developed different workflows, depending on their primary goals for using metagenomics: for example, virus discovery, diagnostics, surveillance and evolutionary studies. Metagenomics studies have revealed trillions of different viruses, especially RNA viruses. Most of these new viruses are only known from sequence data. Only a few of these new viruses will ever be characterized biologically, and most of them may never be directly linked to biological agents, Nevertheless, including all sequences that may represent existing viruses in our classification system is important for research into the ecology, history and impact of the global virome.

\section{CRISPR-Cas}

A major recent development in molecular biology is the powerful CRISPRCas technology. It allows us to alter DNA sequences easily and modify gene function. The acronym CRISPR (Clustered Regularly Interspaced Short Palindromic Repeats) refers to unusual virus-derived, nucleic acid sequences that help protect organisms by identifying attacking viruses and destroying them. In short, organisms like bacteria, use CRISPR-derived RNA (crRNA), which binds to a complementary DNA target, to direct the protein Cas9 ("CRISPR-associated"), an enzyme that cuts foreign strands of DNA. In nature, this system is used by bacteria to destroy viruses. Now, however, it 
has been developed into a laboratory system for gene editing. In such a system, the DNA is cut, and then specific sequences of nucleotides are inserted in the gaps, thus modifying the genome as desired.

In 2018, several studies detailed the use of CRISPR for diagnostic purposes. Assays are described in which activation of the guide RNA by a complementary sequence is followed by indiscriminate cleaving of fluorescent ssRNA or ssDNA probes by Cas13 and Cas12a enzymes respectively. This fluorescent signal can be made visible using isothermal amplification. These are highly promising developments for diagnostics because such CRISPR-Cas based assays are sensitive and specific, and can be performed directly on clinical samples as a single reaction without the need for much equipment.

\section{Viromes, Microbiomes}

Thanks to the latest sequencing techniques, we can now study the complete virome, the whole virus community of different ecosystems. Humans and animals are occupied by large collections of microorganisms. Viruses are even more abundant than bacteria, and mammalian viromes consist of trillions of viruses that are present on and inside the body. These can be viruses that infect humans or animals, but also viruses ingested via food. Most of these viruses do not cause disease, but many infect bacteria that live inside the body or on body surfaces. Despite the abundance of viruses, we know little about what they do. We know that viruses can be important pathogens in humans and that viruses of bacteria, called bacteriophages, can kill bacteria. We combat infectious viruses of humans and animals. Research on pathogenic bacteria is increasingly studying how we can use phage therapy to combat bacterial infections in humans. However, this research only covers a small proportion of the entire viral community. Recent studies indicate that the diverse communities of viruses in our intestinal tract, for example, have a host-microbe interaction relationship with both beneficial and detrimental outcomes for the host. An interesting research question in this respect is whether the virome could be used as a sensitive marker of alterations in a host's health status.

\section{Detecting and combatting pathogenic viruses}

Within Wageningen Bioveterinary Research, these innovative molecular detection and characterization methods have been implemented, optimized and combined into a workflow for virus discovery. The aim is to detect pathogenic viruses in animal disease cases of unexplained aetiology at an 
early stage so that we are better prepared for new and emerging viruses. Different molecular techniques with or without prior knowledge of the genome sequences of the targeted virus are combined in flow charts of analytical methods to search for pathogenic viruses. Regular streams of test materials have been organized with the Netherlands Animal Health Service (GD Deventer) and the Utrecht University Wildlife Health Centre (DWHC). Large numbers of different types of samples from acutely diseased livestock or wildlife are analyzed in this diagnostic pipeline. Depending on the disease history, we usually start with targeted DNA/RNA extraction and processing, followed by PCR and microarray screening. Positive response samples are first characterized by DNA/RNA sequencing and compared with sequences available in databases. Next, they are tested using specific classical laboratory methods, which are still indispensable for biological characterization. Metagenomic analyses are then performed to try to catch all viruses for which no prior sequence information is available. Ultimately, however, we will still have to rely on current information in databases to establish whether detected sequences represent potentially pathogenic agents. As indicated, sequence analysis is followed by in vitro inoculations to characterize the virus further and elucidate its pathogenic potential. Experimental infection studies in animals can also be very helpful in establishing the clinical disease potential of a new virus. However, for ethical reasons this should only be done if really needed, for example, to generate research materials in the case of a new potentially highly pathogenic virus.

\section{Virus Discovery Work Flow}

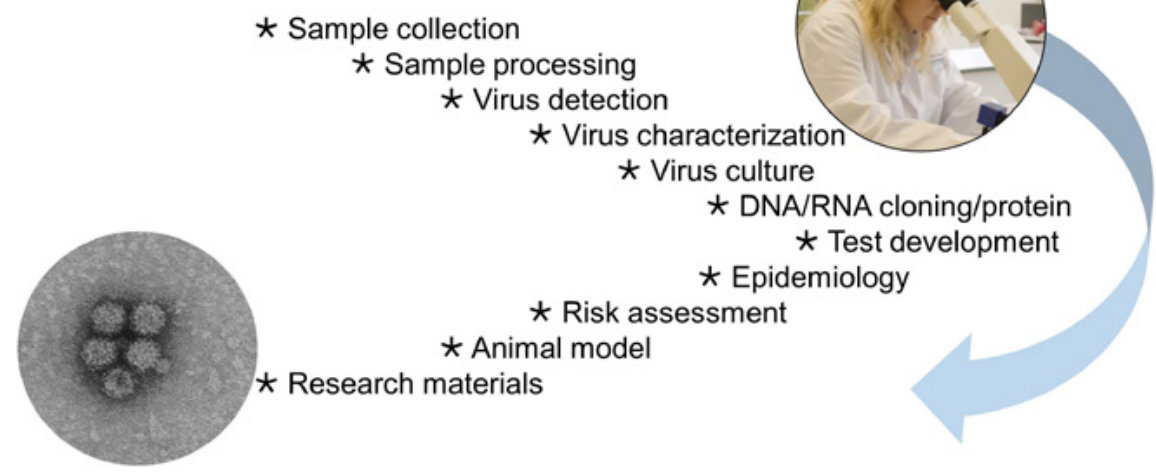

Virus Discovery Workflow, Wageningen Bioveterinary Research. 
Epidemiological studies are the first approach used to determine whether a newly detected pathogenic virus is associated with clinical disease. In the case of a severe acute disease outbreak, rapid disease risk evaluation, using the information available in an early stage of a disease outbreak, is important. Early evaluation of the public health risks is a priority issue. As more data is generated, this can be used to assess transmission rates and the potential for relevant control options. That can be realised by building statistical and mathematical models based on host range, transmission routes, disease reproduction ratio, et cetera. Quantitative epidemiology studies and modelling can be used to assess the effects of interventions. Subsequently, it can be evaluated if these outcomes can be extrapolated to new situations and used to design effective prevention and control strategies.

\section{Virome studies}

A relatively new field of research is the generation of metagenomic data of viral infections to quantitatively study the epidemiology of viral diseases. Livestock and wildlife viromes are detected and characterized using deep sequencing followed by computational approaches for epidemiological analyses. Specific viruses can cause disease, but changes in viromes within body compartments of animals may be associated with disease too. Virus identification by metagenomics approaches (metaviromics in short) together with epidemiologic analyses can be applied to study virus evolution, disease associations and disease transmissions. Subsequently, disease modelling can be done and disease risk assessments made.

\section{Schmallenberg virus detected and controlled}

At our institute, the discovery of the Schmallenberg virus in Dutch cattle and sheep in 2011 is a fascinating example of novel molecular technologies used for virus discovery. In September of that year, a marked reduction in milk yield in dairy cattle was observed on several farms in the Netherlands and Germany. Pooled blood samples from the affected farms were tested using novel molecular approaches. A novel virus was traced by the Friedrich Loeffler Institute using metagenomic analyses. The new virus was named Schmallenberg virus (SBV) after the town of Schmallenberg where the first positive samples came from a dairy farm. Schmallenberg virus is most closely related to viruses of the Sathuperi species, a Simbu serogroup virus within the Orthbunyavirus family. This Schmallenberg virus infection was the first known outbreak caused by a member of the Simbu serogroup in Europe. Simbu viruses like Akabane virus are known to induce 


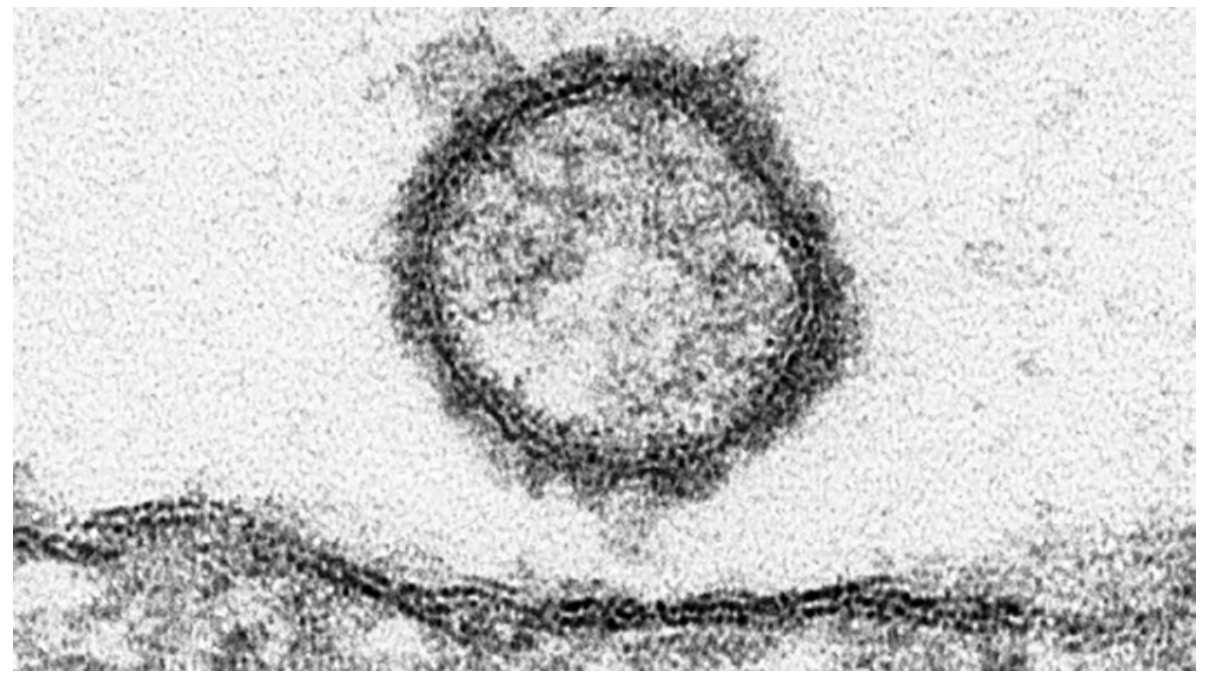

Schmallenberg virus, Electron Microscopy (EM) image. (C) by H. Granzow, FLI, Germany.

malformations if the embryo or foetus is transplacentally infected during a vulnerable period. Immediately after the identification of this new RNA sequence, diagnostic methods were developed and implemented by the Friedrich Loeffler Institute and our group in Lelystad. Malformations that could definitely be attributed to Schmallenberg virus infection were observed from December 2011 onwards in stillborn or new-born lambs, calves and goat kids, which were usually born at term. The first Schmallenberg-virus-induced malformed lambs were confirmed in the Netherlands. The main pathological findings induced by Schmallenberg virus were identical to the changes described for severe Akabane virus infections: bent limbs, fixed joints, twisted neck and spine, short jaw and various malformations of the brain, cerebellum and spinal cord.

As the Simbu serogroup of viruses contains several medically relevant zoonotic viruses, such as Aino virus and Shuni virus, the emergence of Schmallenberg virus triggered a joint veterinary and public health response in the Netherlands to address the possible consequences for human health. In a close collaboration between Wageningen Bioveterinary Research and the National Institute for Public Health and the Environment in the Netherlands, serologic testing with a virus neutralization test was performed to evaluate immunologic responses in exposed people. Fortunately, none of the study subjects showed serologic evidence of Schmallenberg virus infection, 
indicating that the risk of infection through contact with contaminated materials is minimal. Given the high seroprevalence of Schmallenberg virus in affected herds, the lack of any evidence for zoonotic transmission suggests that the public health risk for Schmallenberg virus is absent or extremely low. This was a major relief at the time and an excellent example of veterinary health and public health cooperation.

Following the detection and characterization studies, we did a lot of research on Schmallenberg virus control and the development of effective vaccines. Since 2012, several vaccine products have become commercially available. Therefore, farmers can now vaccinate their sheep and cattle against the disease.

At our institute, research on the Schmallenberg virus has continued in the Zoonoses Anticipation and Preparedness project. This project aims to design new manufacturing processes for delivering effective control tools, such as vaccines and antibodies. These should enable a swift response to major new emerging zoonotic infectious disease threats in Europe and throughout the world. Schmallenberg virus is a prototype virus in this project. Jeroen Kortekaas is the principal investigator on this topic for Wageningen Bioveterinary Research.

\section{Towards a Global One Health approach}

A second important health concept in medicine is the "Global Health" concept. In the $21^{\text {st }}$ century, the term "Global Health" has replaced earlier terms such as "international health" and "tropical medicine". Global Health refers to health issues that concern many countries and is influenced by transnational determinants, such as climate change or urbanization. So here "Global" refers not just to the location of problems but also their scope.

In 2009, in a publication in The Lancet, Jeffrey Koplan proposed defining "Global Health" as 'the area of study, research, and practice that prioritizes improving health and achieving equity in health for all people worldwide. Global health emphasizes transnational health issues, determinants, and solutions. It involves many disciplines within and beyond the health sciences, promotes interdisciplinary collaboration, and is a synthesis of population-based prevention with individual-level clinical care.'

Infectious diseases in biological systems are dynamic: new infectious diseases will appear as infectious agents that contaminate and replicate in all 
biological systems. An example of this is hepatitis E in fecally contaminated drinking water in refugee camps in Africa. New variants of viruses, like HIV, may emerge that are no longer controlled by the vaccines or antivirals applied in the population. Past experiences in infectious disease control demonstrate that a single set of measures is insufficient for a single disease. We need to do more than build a sewage system or provide just vaccines, for example. Infectious diseases should not only be considered from a biomedical perspective, but also in relation to the natural environment and its anthropogenic influences. A systems approach should preferably be used in which positive and negative factors for transmission and disease spread are taken into account. This can be defined as a "Global one health approach": 'The combined effort of multiple disciplines to improve the health of humans, animals and plants within sustainable ecosystems at the global level by using an integrated systems approach to come to transnational and global policy, research and practices.'

On a global scale, eradication of infectious diseases is a goal of international organizations: the WHO for human medicine, the FAO and OIE for veterinary medicine, and the FAO for plant diseases. Cases of viral disease eradication, smallpox and rinderpest, are landmark achievements. Unfortunately, however, this list is not very long. Initially, eradication of a disease is often attempted, especially when the disease has severe consequences and mitigating measures, for example, vaccination, are scarcely possible. Later on, one or more mitigation options may become available. Then the aim will be to prevent the disease using a combination of eradication and mitigation strategies.

This is how Ebola was dealt with in Africa. During the 2014-2016 outbreak in West Africa, the initial focus was on biocontainment and eradication. Later on, newly developed vaccines were applied, and finally, the combined efforts led to the disease's eradication. In the current outbreak in Congo, the need to consider multiple factors to control the disease has once again become clear. The Ebola vaccine is proving highly effective, but distrust of health workers, skepticism of the disease's existence or origin, and attacks on medical facilities are frustrating progress.

\section{Wageningen University investment theme "Global One Health"} In 2015, we started the Wageningen University and Research investment theme "Global One Health". This theme was initially coordinated by Willem 


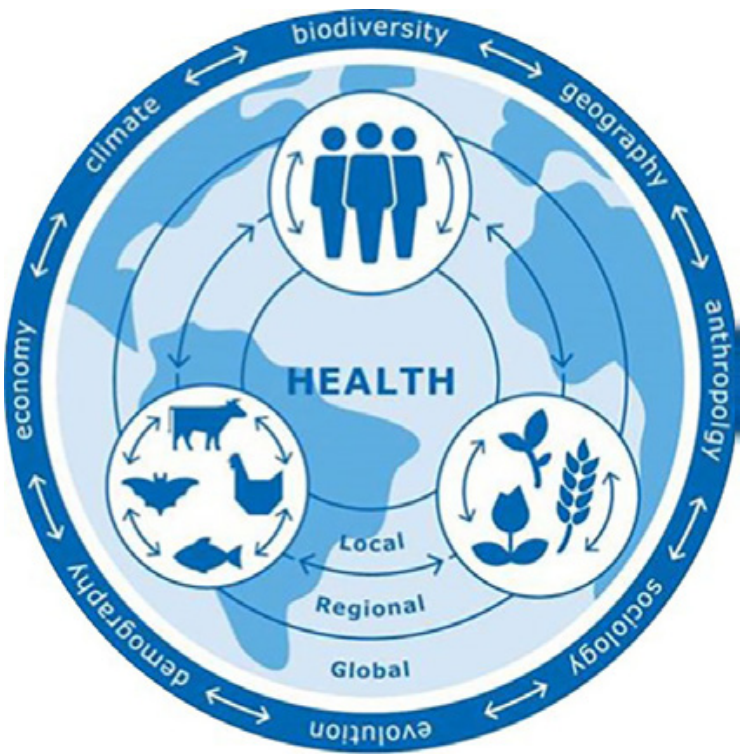

Determinants of Global One Health and Their Interactions.

Takken and I, and later on, Marcel Zwietering took over Willem Takken's role. In just three years, twelve multidisciplinary research projects were started and successfully completed within this research theme. In all projects, there was a cooperation between a Wageningen Research unit and a Wageningen University department. A core group with representatives from all departments working on health research was formed, which acts as the research steering committee of the theme. Primary research outcomes included analyses of socioeconomic factors influencing the emergence of new zoonotic infection outbreaks, assessments of the risks of antimicrobial resistance in manure applied on crop fields, and analyses of the gut microbiome of virus-transmitting insects. With the theme research group, we have organized annual research symposia and several successful workshops, and the theme has also acted as a generator for several new projects in the field of One Health. I will discuss several of these later.

In 2018, we established an international Global One Health network with three other top-ranked agricultural universities: University of California in Davis, USA, Nanjing Agricultural University in China and Massey University in New Zealand. This network enables PhD exchanges, and we are currently working on a Global One Health cooperative research programme for this network. 


\section{Netherlands Centre for One Health}

The Netherlands Centre for One Health $(\mathrm{NCOH})$ is an important national collaboration to tackle the global risks of infectious diseases. It is a network of academic research institutes in the Netherlands, which commits to creating durable solutions for major infectious disease challenges using an integrated One Health approach. $\mathrm{NCOH}$ was founded by Wageningen University and Utrecht University in February 2016. It has one common Strategic Research Agenda with four complementary Strategic Research Themes: Emerging Infectious Diseases Preparedness, Tackling Antimicrobial Resistance, Smart and Healthy Farming, and Healthy Wildlife and Ecosystems.

Dick Heederik of Utrecht University chairs the NCOH executive board. As principal investigator of Wageningen University and Research, I collaborate with the different theme leaders within the network. Recently, under the coordination of Marion Koopmans, of Erasmus University Rotterdam, we submitted a large research proposal in response to the "Dutch National Research Agenda" call. This proposal focusses on new emerging insecttransmitted viruses and comprises research ideas of several Wageningen University colleagues, including Mart de Jong, Monique van Oers, Gorben Pijlman, Sander Koenraadt, Fred de Boer and Jeroen Kortekaas.

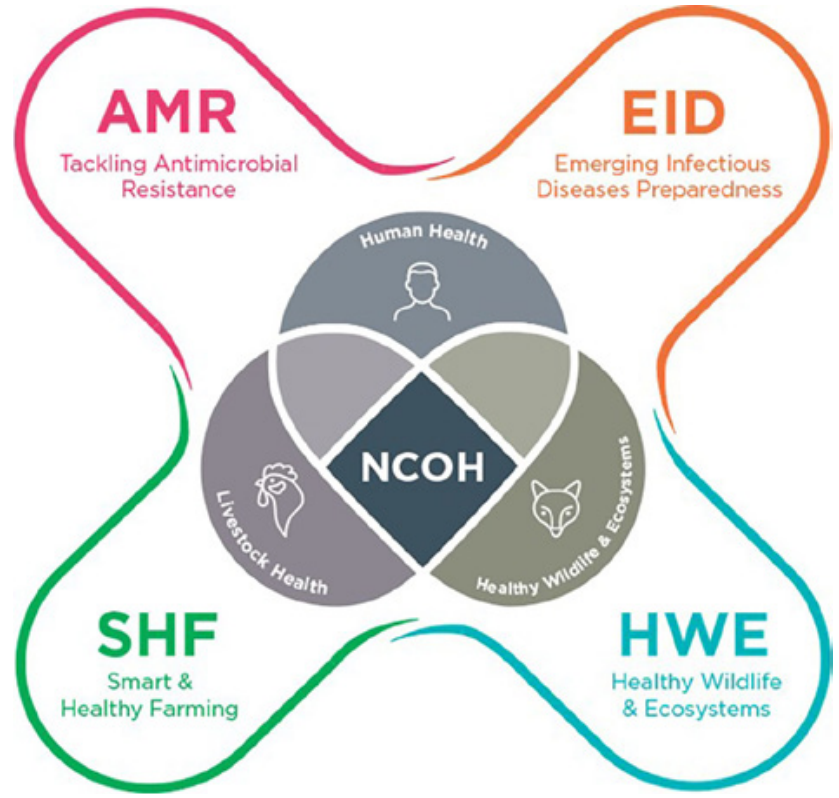

Netherlands Centre for One Health (NCOH) Research Themes. 


\section{The One Health European Joint Programme (One Health EJP)}

A European example of implementing the One Health concept is the One Health European Joint Programme. This has realized a partnership between 38 acclaimed food, veterinary and medical laboratories and institutes across 19 Member States in Europe. In line with the "Prevent-Detect-Respond" concept, the main focus of this 5-year EU programme is to reinforce collaboration between institutes by enhancing transdisciplinary cooperation and integration of activities. This will be achieved by developing dedicated Joint Research Projects (JRPs) and Joint Integrative Projects (JIPs), and establishing education and training in the fields of Foodborne Zoonoses (FBZ), Antimicrobial Resistance (AMR) and Emerging Threats (ET) is established.

Most of the 38 partner institutes have reference responsibilities, representing a sustainable framework for an integrated research community. By collaborating more closely, the EJP partners can align their approaches, increase their knowledge and improve epidemiological studies and risk assessments. The ultimate goal is to provide risk managers with suitable prevention and control strategies and the best tools for intervention measures. Within this EJP project, Wageningen Bioveterinary Research collaborates with many European research institutes in a growing number of internal research projects as well as integrative projects. Half of the funding comes from the EU and half from national governments. On the national side, research details are discussed with the Ministry of Health, Welfare and Sport and the Ministry of Agriculture, Nature and Food. Within Wageningen Bioveterinary Research this is also tuned with Willie Loeffen, Head of the Statutory Tasks Unit for Transmissible Animal Diseases. As a member of the project management board, I act as the point of contact for Wageningen Bioveterinary Research and assist in developing and realizing all projects we are involved in.

\section{Chair research and education themes}

In this chair, I aim to work on at least three themes for research and education: 1. Detection and characterization of new emerging viruses, 2. Infection and epidemiology of zoonotic viruses, and 3. Global One Health.

Within the theme "Detection and characterization of new emerging viruses", I will continue my research on the preparedness for new and emerging 
viruses and constantly try to detect pathogenic viruses in animal disease cases of unexplained aetiology at an early stage. This work will result in a lot of new data about circulating viruses and related research objectives. So there will be plenty of relevant topics for master or PhD students to work on a thesis at Wageningen Bioveterinary Research in Lelystad, such as data evaluation, additional laboratory testing or epidemiological studies.

Metagenomics will be applied to study viromes within different livestock species. A study on the pig gut microbiome will be realized as part of an emerging risks study within the new Wageningen Research theme "Healthy and Safe". Current and new omics analyses will be used to try to assess host immunity and expected susceptibility to new virus infections. Together with the group of Alex Bossers, we will start a PhD project on metagenomic aspects related to goat farms in the Netherlands. This study is part of the VGO III project ("Veehouderij en Gezondheid Omwonenden" III/"Health of residents living nearby livestock farms") project.

The theme "Infection and epidemiology of zoonotic viruses" includes foodborne viruses and our research in this theme will primarily focus on hepatitis E virus. Basic and applied research will assess the public health threats and how to control such a zoonotic virus in the food production chain. Two PhD students in our group are currently working on hepatitis. Renate Hakze is studying the infectivity of circulating hepatitis E viruses in the Netherlands. Marina Meester is studying biosecurity options for hepatitis E virus in pig farms in cooperation with Arjan Stegeman and Tijs Tobias from Utrecht University. Pulled by Marcel Hulst and Tinka Jelsma we continue our work on inactivation of viruses in the food and feed production chains.

As part of the first phase course "Health Issues in Daily Life; a Bèta-Gamma Approach" of the Department of Social Sciences, I will continue my lectures on the hazards of zoonotic and foodborne viruses. I aim to work closely with the Chair Group Virology of professor Monique van Oers, and other Wageningen University groups as appropriate, to develop and implement courses related to virology and to realize viral zoonoses research. The stability and persistence of viruses in mammalian host populations and their environment will be a topic of interest for education within this theme.

In the "Global One Health" theme, I will continue to stimulate interdisciplinary research cooperation. A primary research objective is to 
further develop a coherent vision and a systems approach for multidisciplinary research. This will build on and combine current expertise fields in Wageningen to genuinely integrate scientific responses to Global One Health challenges.

We have developed a "Global One Health" Summer Course in Wageningen together with Henk Hogeveen and the support of many others. It will be given for the third time this year and in future years subject to demand. Led by Sander Koenraadt and supported by Marcel Zwietering and Marcel Verweij, we have submitted a proposal as the Global One Health Core Group for a bachelor minor on "Global One Health". In short, the learning outcomes include: a) Understand basic concepts in health research, b) Understand connections and conflicts of health research, c) Ability to implement a multidisciplinary approach in health research.

In all three themes, a significant part of my time will be devoted to MSc and $\mathrm{PhD}$ education. I will focus on supervising the writing of MSc and $\mathrm{PhD}$ theses and supporting the necessary training for this. MSc students and PhD students will have the option of an internship for laboratory training at Wageningen Bioveterinary Research under my supervision. 


\section{Conclusion}

As I come to the end of this inaugural address, I conclude that emerging viral diseases can have a huge impact on society. Preparedness for and control of new and emerging viral diseases is very challenging. It needs to be addressed through the collaboration of all health-related research disciplines using a multidisciplinary Global One Health approach. A growing number of innovative methods are being developed in infectious disease research.

We should all use these as much as possible to prevent and control emerging infectious diseases both now and in the future. 


\section{Afsluiting}

Aan het einde van deze inaugurele rede wil ik graag een aantal mensen bedanken. Maar eerst wil ik zeggen dat de discussie over het gebruik van de Nederlandse taal in het onderwijs mij niet is ontgaan. Ik ben niet van mening dat het Nederlands uit het onderwijs moet verdwijnen. Ik ben wel van mening dat wetenschappelijk onderzoek internationaal gedeeld moet worden, en dat onderzoek en hoger onderwijs met elkaar verbonden dienen te zijn. Ook het onderwijs wordt daarmee meer internationaal en de taal van $1^{\mathrm{e}}$ keuze is het Engels. Ik heb daarom zonder meer gehoor gegeven aan de wens van de Universiteit om deze inaugurele rede uit te spreken in het Engels.

Dan nu het dankwoord: Arthur Mol, Rector Magnificus en Louise Fresco Voorzitter van de Raad van Bestuur van de Wageningen Universiteit wil ik bedanken voor het mogelijk maken mijn aanstelling als bijzonder hoogleraar bij Wageningen Universiteit. Ludo Hellebrekers, directeur van Wageningen Bioveterinary Research en Martin Scholten directeur van de Animal Sciences Group van Wageningen Research wil ik bedanken voor het in mij gestelde vertrouwen. De goede samenwerking met jullie beide heeft een belangrijke bijdrage geleverd aan het ontwikkelen van de onderzoekdisciplines waarbinnen ik actief ben. Ik hoop dat we dat in de komende jaren kunnen voortzetten.

Mart de Jong leerstoelhouder quantitatieve veterinaire epidemiologie wil ik bedanken voor de ruimte die ik heb gekregen binnen zijn leerstoelgroep. Ik heb veel bewondering voor je enorme mathematische en epidemiologische kennis. Samen met collega hoogleraar Ynte Schukken en de andere medewerkers van de groep zijn we enthousiast begonnen aan een mooie samenwerking met kerndisciplines epidemiologie en infectieziekten. Ik heb er veel vertrouwen in. Met de andere leerstoelhouders binnen de Animal Sciences Group zijn er inmiddels ook samenwerkingen. Ik ben er van overtuigd dat we dat in de komende jaren kunnen uitbreiden.

Mijn promotores Professor Arie Brand en Professor Jan van Oirschot ben ik dankbaar voor de inleiding in de wetenschap en de liefde voor de virologie. Ik denk nog regelmatig terug aan de adviezen die jullie mij gegeven hebben. Mijn collega's van Wageningen Bioveterinary Research in Lelystad wil ik bedanken voor de vele dingen die ze in de afgelopen jaren voor mij gedaan hebben. Van reizen boeken, financiële overzichten en video-opnames tot ingewikkelde wetenschappelijke experimenten. Teveel om op te noemen. Zonder jullie had ik hier nooit kunnen staan. 
Mijn contactpersonen bij opdrachtgevers Ministeries van Landbouw Natuurbeheer en Voedsel, en Volksgezondheid Welzijn en Sport, Christianne Bruschke, Frouke de Groot, Annemarie Bouma, Francoise Divanach, Yvonne de Nas en Stephanie Wiessenhahn bedank ik voor alle nuttige besprekingen over onderzoek door de jaren heen.

Virussen en vooral het onderzoek daarnaar is niet aan grenzen gebonden en Global One Health" is per definitie een wereldwijde uitdaging. Dat betekent dat ik samenwerk met heel veel buitenlandse onderzoekers en onderzoeksinstituten. Ik ben lid van diverse internationale organen, commissies en besturen. Al de collega's die ik daarbij tegenkom ben ik dankbaar voor de vele vruchtbare samenwerkingen.

Mijn ouders wil ik bedanken voor het feit dat ze mijn studie mogelijk gemaakt hebben. Mijn vader kan dit moment helaas niet meer meemaken, het zou hem vervuld hebben met veel trots. Ik ben blij dat mijn moeder, mijn broer en al mijn zussen hier allen aanwezig zijn. Dat onderstreept de goede familierelatie.

'Last but not least' mijn gezin. Moniek bedankt dat je me altijd de ruimte hebt gegeven om me in te zetten voor mijn werk, en voor het feit dat je altijd graag bereid was om kritisch te kijken naar de communicatie over ons onderzoek vanuit het perspectief van het publiek. Loran met jou deel ik de liefde voor de sport. Ik hoop dat we de doelpunten van Ajax nog vaak kunnen bespreken. Jarne, met jou deel ik de liefde voor Europa. Het zou me niets verbazen als we elkaar met werk in Brussel nog eens tegenkomen. We zien elkaar lang niet elke dag meer maar jullie drieën zijn mijn thuis. Of het nou met vakantie is of met een feestje of een etentje, Ik hoop dat we nog heel veel quality time met elkaar kunnen beleven.

Tenslotte, in gedachte nog even terug naar die bewuste 12 maart 2003. Sinds het uitbreken van SARS, zijn er heel veel nieuwe ontwikkelingen in de biomedische wetenschap. Met de overtuiging dat alle gezondheidgerelateerde wetenschappen met elkaar moeten samenwerken in een Global One Health benadering, en dat disciplines binnen de virologie nauw met elkaar verbonden moeten zijn, zullen we in de toekomst beter voorbereid zijn op nieuwe bedreigende virusziekten.

Ik heb gezegd. 


\section{References}

Aspinall EJ, Couturier E, Faber M, Said B, Ijaz S, Tavoschi L, Takkinen J, Adlhoch C. Hepatitis E virus infection in Europe: surveillance and descriptive epidemiology of confirmed cases, 2005 to 2015. Euro Surveill. 2017, Jun 29;22(26). doi: 10.2807/1560-7917.ES.2017.22.26.30561.

Beer M, Conraths FJ, van der Poel WH. 'Schmallenberg virus'--a novel orthobunyavirus emerging in Europe. Epidemiol Infect. 2013, Jan;141(1):1-8. doi: 10.1017/S0950268812002245.

Budka, H. 2011. Editorial: The European Response to BSE: A Success Story. EFSA Journal 9: e991.

Chiu C. Cutting-Edge Infectious Disease Diagnostics with CRISPR. Cell Host Microbe. 2018, Jun 13;23(6):702-704. doi: 10.1016/j.chom.2018.05.016.

EFSA. Public health risks associated with hepatitis E virus (HEV) as a food-borne pathogen. EFSA scientific opinion. 11 July 2017. https://doi.org/10.2903/j.efsa.2017.4886.

Fresco L.O. et al. Global One Health - a new integrated approach (2015). https://www.wur.nl/ upload_mm/5/8/7/49dd32b6-6218-43e8-a742-fbd8e1a0fcca_GOH_Final_20150602.pdf (accessed 25 April 2018)

Hille F, Richter H, Wong SP, Bratovič M, Ressel S, Charpentier E. The Biology of CRISPR-Cas: Backward and Forward. Cell. 2018, Mar 8;172(6):1239-1259. doi: 10.1016/j.cell.2017.11.032.

Jinek M, Chylinski K, Fonfara I, Hauer M, Doudna JA, Charpentier E. A programmable dual-RNA-guided DNA endonuclease in adaptive bacterial immunity. Science 2011, 337 (6096): 816-21. Bibcode:2012Sci. 337..816J. oi:10.1126/science.1225829. PMID 22745249.

Koplan JP, Bond TC, Merson MH, Reddy KS, Rodriguez MH, Sewankambo NK, Wasserheit JN; Consortium of Universities for Global Health Executive Board. Towards a common definition of global health. Lancet. 2009, Jun 6;373(9679):1993-5. doi: 10.1016/S01406736(09)60332-9.

Kumar A, Murthy S, Kapoor A. Evolution of selective-sequencing approaches for virus discovery and virome analysis. Virus Res. 2017, Jul 15;239:172-179. doi: 10.1016/j. virusres.2017.06.005.

Jones KE, Patel NG, Levy MA, Storeygard A, Balk D, Gittleman JL \& Daszak P. Global trends in emerging infectious diseases. Nature, 2008, volume 451, pages 990-993.

Li W1, Shi Z, Yu M, Ren W, Smith C, Epstein JH, Wang H, Crameri G, Hu Z, Zhang H, Zhang J, McEachern J, Field H, Daszak P, Eaton BT, Zhang S, Wang LF. Bats are natural reservoirs of SARS-like coronaviruses. Science. 2005, Oct 28;310(5748):676-679.

Mehand MS, Al-Shorbaji F, Millett P, Murgue B The WHO R\&D Blueprint: 2018 review of emerging infectious diseases requiring urgent research and development efforts. Antiviral Res. 2018, Nov;159:63-67. doi: 10.1016/j.antiviral.2018.09.009.

Mokili JL, Rohwer F, Dutilh BE. Metagenomics and future perspectives in virus discovery. Curr Opin Virol. 2012, Feb;2(1):63-77. doi: 10.1016/j.coviro.2011.12.004.

Reusken C, van den Wijngaard C, van Beek P, Beer M, Bouwstra R, Godeke GJ, Isken L, van den Kerkhof H, van Pelt W, van der Poel W, Reimerink J, Schielen P, Schmidt-Chanasit J, Vellema P, de Vries A, Wouters I, Koopmans M. Lack of evidence for zoonotic transmission 
of Schmallenberg virus. Emerg Infect Dis. 2012, Nov;18(11):1746-54. doi: 10.3201/ eid1811.120650.

Van der Poel WH. Food and environmental routes of Hepatitis E virus transmission. Curr Opin Virol. 2014, Feb;4:91-6. doi: 10.1016/j.coviro.2014.01.006.

Van der Poel WHM, Dalton HR, Johne R, Pavio N, Bouwknegt M, Wu T, Cook N, Meng XJ. Knowledge gaps and research priorities in the prevention and control of hepatitis $E$ virus infection. Transbound Emerg Dis. 2018, May;65 Suppl 1:22-29. doi: 10.1111/tbed.12760.

Parashar UD, Anderson LJ. Severe acute respiratory syndrome: review and lessons of the 2003 outbreak. International Journal of Epidemiology, 2004, Volume 33, Issue 4, 628-634, https:// doi.org/10.1093/ije/dyh198.

Simmonds P, Adams MJ, Benkő M, Breitbart M, Brister JR, Carstens EB, Davison AJ, Delwart E, Gorbalenya AE, Harrach B, Hull R, King AM, Koonin EV, Krupovic M, Kuhn JH, Lefkowitz EJ, Nibert ML, Orton R, Roossinck MJ, Sabanadzovic S, Sullivan MB, Suttle CA, Tesh RB, van der Vlugt RA, Varsani A, Zerbini FM. Consensus statement: Virus taxonomy in the age of metagenomics. Nat Rev Microbiol. 2017, Mar;15(3):161-168. doi: 10.1038/ nrmicro.2016.177.

Wilhelmsson, P., P. Lindblom, L. Fryland, J. Ernerudh, P. Forsberg, and P. E. Lindgren. Prevalence, Diversity, and Load of Borrelia species in Ticks That Have Fed on Humans in Regions of Sweden and angstrom land Islands, Finland with Different Lyme Borreliosis Incidences. PLoS ONE 2013, 8.

Zinsstag J, Schelling E,, Waltner-Toews D, Tannera M. From "one medicine" to "one health" and systemic approaches to health and well-being. Prev Vet Med. 2011, Sep 1; 101(3-4): 148-156. doi: 10.1016/j.prevetmed.2010.07.00. 



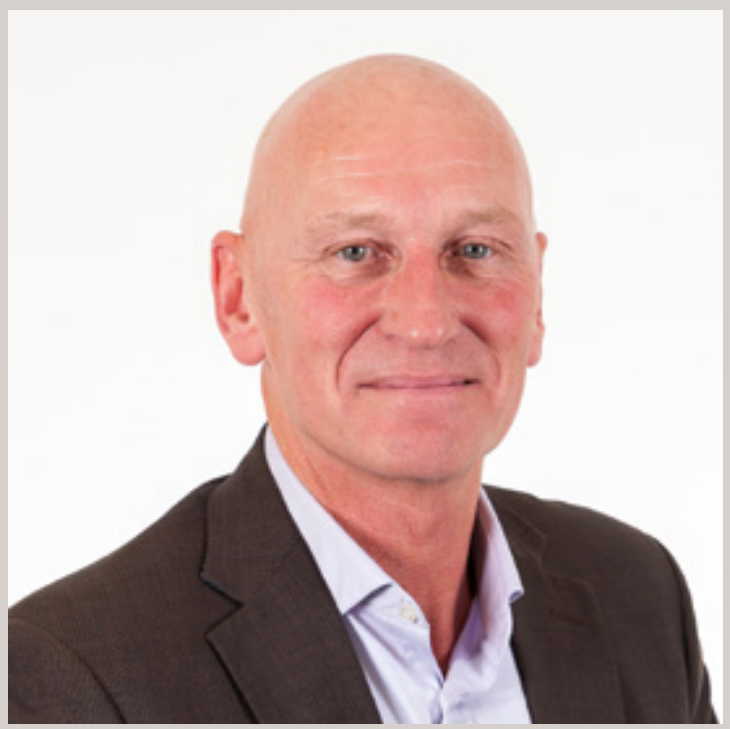

Prof.dr Wim H. M. van der Poel

'New emerging infectious disease outbreaks are complex events that can have a huge impact on society. Preparedness for and control of new and emerging viruses is very challenging. For prevention and control of emerging diseases, collaboration of all health-related research disciplines will be needed, using a multidisciplinary Global One Health approach. A growing number of innovative molecular methods are being developed in infectious disease research. We should all use these as much as possible to prevent and control new and emerging viruses effectively, both now and in the future' 